\title{
THE FUTURE OF THE EUROPEAN UNION: THE ROLE SUPRANATIONAL PUBLIC SPHERE AND THE WELFARE STATE POLICIES
}

\section{Levent KIRVAL ${ }^{*}$}

\section{Abstract}

This paper focuses on the reasons of the legitimacy deficit of the European Union's (EU) political institutions and explains why the EU is not considered as legitimate as the nation-states by the European citizens today. One key claim is that although the democratic participation in the decision making mechanisms and the welfare state policies have played a crucial in the nation-states' legitimisation processes; these have been greatly lacking at the EU level. Instead of portraying the EU and the nation-state as two continuously conflicting sovereignty areas, this paper tries to formulate a theoretical political model for the EU which is inspired from the experiences of the nation-states. This proposed model (for solving the legitimacy deficit of the EU institutions) is based on communication, hybrid supranational identity and public sphere, which are backed by social policies at the supranational level.

Keywords: European Union, Legitimacy Deficit, Supranational PublicSphere, European Welfare-State Model

\section{$\ddot{O}_{z e t}$}

Bu makale Avrupa Birliği'nin (AB) siyasi kurumlarının meşruiyet açı̆̆ nedenleri üzerinde durmakta ve AB'nin, bugün, Avrupa vatandaşlarl tarafindan ulus-devletler kadar neden meşru görülmediğini ortaya koymaya çalışmaktadır. Bu çerçevede, AB düzeyinde eksik olan en önemli husus olarak; ulus-devletlerin meşruiyet kazanım süreçlerinde de kilit rol

* Asst. Prof. Dr., Istanbul Techinal University, Maritime Faculty, e-mail: lkirval@itu.edu.tr 
oynayan; karar alma süreçlerine demokratik katılım ve refah devleti politikalarının yetersizliği, ortaya çıkmaktadır. Makale, ulus-devleti ve AB'yi sürekli çatışan iki egemenlik alanı olarak resmetmek yerine, ulusdevletlerin deneyimlerinden esinlenerek, AB için siyasal bir teorik model formüle etmeye çalışmaktadır. AB kurumlarının meşruiyet açığını azaltmak için önerilen bu model; uluslar-üstü düzeyde sosyal politikalarla desteklenen; iletişim temelli, hibrid uluslar-üstü bir kimlik ve kamusal alana dayanmaktadir.

Anahtar Keliemeler: Avrupa Birliği, Meşruiyet Açı̆̆g, Uluslarüstü Kamusal Alan, Avrupa Sosyal Devlet Modeli

\section{Introduction}

For the last half century, Europe has put in practice the measures for the peaceful neighbourly cohabitation. Unquestionably, the two World Wars were crucial in the development of this attitude, which Etienne Balibar calls as 'the lesson of tragedy'. 'After hundreds of years with wars and bloodlettings, Europe has come to the moment of awakening and started to experiment a trans-national public order: a kind of setting in which Clausewitz's rule no longer binds and wars are neither neutral, nor permissible extensions of political action'. ${ }^{2}$

For Balibar, two important learning processes have been behind this important transformation. First was related with the growing consciousness of the realities of colonial history. Europe divided the world into the realms of 'civilisation' and 'barbarism' for centuries. However, in time, it started accept that the greatest barbarity was not on the side it had imagined. Secondly, Europe's long involvement with the rest of the world has reverberated into a powerful, irreversible process of hybridisation and multiculturalism now further transforming Europe. ${ }^{3}$

However, as Bauman calls it, Europe is still an unfinished adventure. Its full transformation towards supra-nationalism will take time. But this

${ }^{1}$ Balibar, Etienne, 'Europe: Vanishing Mediator', Constellations, Volume 3, 2003. p. 312

${ }^{2}$ Bauman, Zygmunt, Europe: An Unfinished Adventure, Cambridge: Polity Press, 2004. p. 40

${ }^{3}$ Balibar, op. cit. pp. 312-338 
transformation is still inescapable as the EU opened the Pandora's Box by means of creating a political model functioning with the participation of different nation-states (now, member states). To this end, this paper proposes that the EU can be successful in such a transformation only by utilising political theory approaches. Particularly, it will try to give the legitimisation processes of the nation-states as a major way out for the problems that are confronting us at the supranational level.

\section{Argument in Context}

The legitimisation of the nation-state structures was a gradual process. There have been pressures on individuals to accept the newly flourishing central authority forms. However, consent was (and still is) the most important factor in the functioning of the nation-states' institutions. In this context, the tools that helped the nation-states to get the consent of their citizens can still be inspiring today.

On the whole, the political rights have been the first important axis of the legitimisation processes of the nation-states. The identity of the individuals was mostly defined by the concept of citizenship and this provided the basic political rights for all. The second important dimension of the legitimisation of the nation-states has been the social service providing character of the model. The political rights have been backed by the social rights, and these two dimensions have been crucial in the increasing legitimacy of the nationstates as dominant political forms. Hence, the legitimacy of the political model has been strengthened by the combination of the "input" and "output" dimensions. ${ }^{4}$

Following a similar logic, Seymour Martin Lipset and Stein Rokkan ${ }^{5}$ underlined the existing cleavages in a society and argue that, historically,

${ }^{4}$ Fritz Scharph gives us these two different legitimisation paths, though the most successful example for him would be a combination of the both. Legitimacy by inputs is the society's approval of the political structures due to participation in the decision making mechanisms. Legitimacy by outputs on the other hand is the society's approval of the political structures due to the services they provide. Scharpf, Fritz, Governing in Europe: Effective and Democratic?, New York: Oxford University Press, 1999.

${ }^{5}$ Seymour M. Lipset and Stein Rokkan (Eds.), Party Systems and Voter Alignments: Cross-National Perspectives, New York: Free Press, 1967. 
the political regimes/institutions (and their political parties) are formed in parallel with these cleavages. For them, one can find the origins of politically relevant cleavages of the late 20th century in nation building 'the National Revolution' - and in industrialisation - the Industrial Revolution.

The transition from rival principalities/feudalism to nation states led to the emergence of the dominant 'center-periphery' and 'state-church' cleavages. On the other hand, the Industrial Revolution produced two other cleavages: 'urban-rural' and 'owner-worker'.

Lipset and Rokkan argue that the European nation-states and their institutions have played key roles in the containment of these cleavages. Furthermore, their institutions have developed in parallel with these cleavages in European societies, and also managed to satisfy/control the wishes of the respective parties' (emerging around these cleavage lines).

In time, the evolving citizenship model of the nation-states involved three basic sets of rights: civil, political and social rights (cross-cutting the four cleavage lines of Lipset and Rokkan). ${ }^{6}$ To a great extent, the civil rights are defined as the legal equality (in a secular model) and the political rights are described as the extension of this equality to all the society by means of a participatory model.

The development of the social rights dimension of the citizenship has been mostly a result of the collapse of the classical liberal market model in the early twentieth century. In the 'Great Transformation', Karl Polanyi presents a powerful discussion of the disastrous implications of the commodification of land and labour during those years. ${ }^{7}$ These criticisms have been crucial in the increasing social dimension of the nation-states (welfare state compromise) and the strengthening of the Keynesian central planning in the following decades.

However today, the clash between the supporters of liberal competitiveness based market models and more socially oriented market structures still persist. Although the liberals still believe in the self-

${ }^{6}$ Marshall, T. H., Citizenship and Social Class, London: Cambridge University Press, 1950.

${ }^{7}$ Polanyi, Karl, The Great Transformation, New York: Beacon Press, 2001. 
regulating character of the market and its infallible demand and supply basis, we are seeing that today the protection of the mankind and natural substance of society is still at stake and the so-called 'self-regulating' market system does not work for the benefit of all. Life and livelihood of millions of people have become more insecure and the dimensions of environmental degradation are alarming. In the context of the contemporary transformations of the world economy, social policy and related questions of responsibility and agency acquire a novel significance.

One can say that these questions pertaining to the social rights call for the re-examination of the role of the state in these areas. Additionally, the individuals' demands for further participation in the political processes are also increasing the pressures on the governance forms to further develop political and civil rights. Therefore; although Marshall's account of citizenship can be applied to any society, at any given time (to a great extent); we can also say that the nation-state continues to evolve even today. That said; its basic democratic participation and social welfare characteristics are still capable of being an inspiration for the EU. In fact, by following the footsteps of the nation-states (and its gradual evolution) the EU may put into practice more inclusive and socially oriented policies at the supranational level.

Surely, in an enlarging Union, the convergence of the different identities within a supranational political membership model will be a difficult challenge. However, following Jurgen Habermas, one can still argue that this may still be possible. Habermas separates political membership in a community (demos) from identities (ethnos) and argues that the creation of political membership model at the supranational level is still a possible option. According to him;

"A common European political culture based on the rule of
law, separation of powers, democracy, respect for human
rights etc. would guarantee the flourishing of equally
legitimate cultural forms of life",

\footnotetext{
${ }^{8}$ Habermas, Jurgen, 'Citizenship and National Identity: Reflections on the future of Europe' in Praxis International, Volume 12, 1992. pp. 1-19
} 
Habermas separates the demos and ethnos, and puts the European political identity that can be shared by all the citizens regardless of their own national identities and subcultures as the driving force of European integration. Institutions and the legal framework are crucial in the development of such a supranational identity. This model is also capable of keeping the ethnos within the model by the development of multicultural supranational institutions and the relevant legal framework.

Besides being important for the development of such a multicultural model defined by political rights, supranational institutions are also crucial for strengthening the social policy realms in Europe. The legitimacy of a political structure cannot be solely established by increasing the political participation options of the masses. The commodification of the social life also leads to the commodification of the democratic processes, which leads to the increasing political influence of the haves against the have-nots. Therefore, the political institutions should be capable of protecting the individual against the destructive effects of the solely profit oriented markets.

Furthermore, a common European identity defined by democracy and political rights can be more easily created when there is an effectively working political model that provides social services to the individuals. In fact, this may also necessitate (to some extent) a return to the prior Keynesian economic policies. A combination of the 'laissez faire laissez passé' model, the Keynesian planning and the welfare state can be the solution of the problems that we are facing today at the national and regional/supranational levels.

Today, the political-civil and social rights are still crucial for the legitimisation of the political regimes. In this context, the EU should focus on the steps of its predecessor in these areas to solve its legitimacy related problems. Moreover, it also has to go beyond these steps for further deepening the supranational institutions and being able offer a supranational identity and citizenship alternative.

However, when we look at the current situation what we are seeing is that the EU is considered as mostly an elite project with limited mass participation, and it is also generally regarded as a liberal common market model that lacks social policies. 


\section{The Signs of the Legitimacy Deficit in the EU}

Today, the EU greatly influences the daily lives of the individuals and the policy domains of the nation-states. But, it is difficult to say that the EU is considered as legitimate as the nation-states, at least for most of the European electorate.

\section{Table-1}

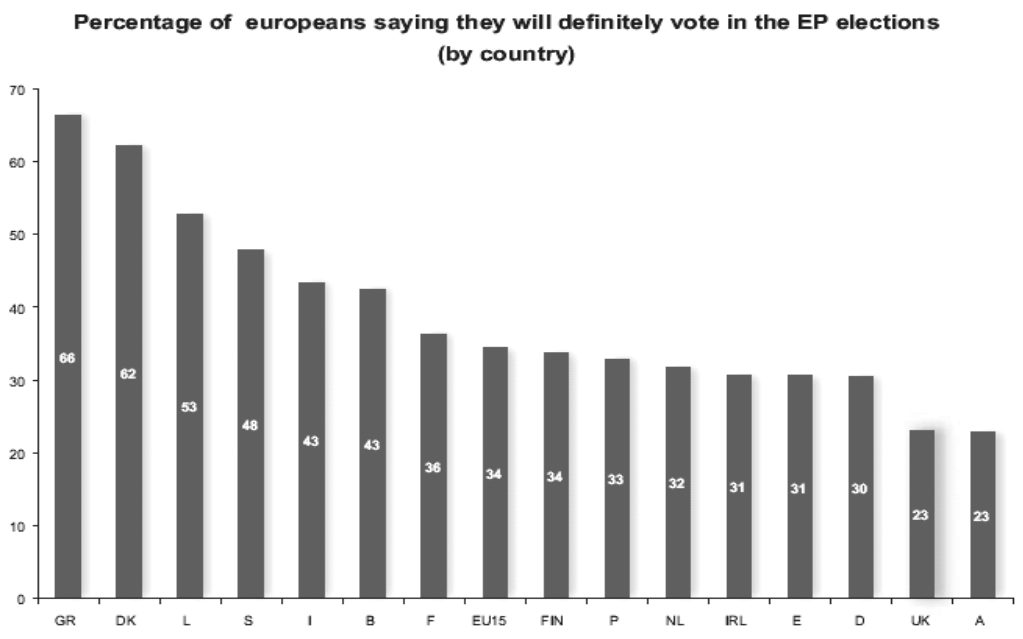

Source: Standard Eurobarometer Public Opinion Survey 61, 'European Opinion Research Group' Series, Spring 2004. p. 13

The above table shows us that the legitimacy of the European institutions is still highly questionable. Today, the European Parliament is the only institution for which the Europeans can directly elect representatives. The European Parliament gained considerable power in the EU decision making mechanisms in time. However, most of the Europeans do still seem to consider it as an ineffective body. The low voter turnouts during the European elections show us that the EU's political institutions are considered as less important for the European electorate. It is clear that the European elections are considered as "second order" elections for most of 
the Europeans. The data gets more convincing when the voters are asked about the reasons for deciding on whom to vote in the European elections.

\section{Table-2}

Most important reasons for deciding for whom to vote

\begin{abstract}
The policies of the candidate(s)
Your opinion about national issues

Your opinion about European issues
\end{abstract}

The party of the candidate(s)

The personality of the candidate(s)

Don't know

Other (SPONTANEOUS)

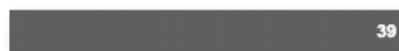

38

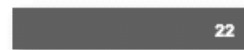

17

10

3

Source: Standard Eurobarometer Public Opinion Survey 61, 'European Opinion Research Group' Series, Spring 2004. p. 14

Here, it can be clearly seen that the voters do still consider the national issues as more important compared with the European ones even in the European elections. The decisions about the supranational level are still given by the national considerations and this shows that the assumed power of the nation-states is much higher than the European institutions. Interestingly, when the individuals are asked about their views on the impact of national and European institutions on their daily lives, the data again shows us that the nation-states have more assumed power. 


\section{Table-3}

Impact of national and European institutions on citizens

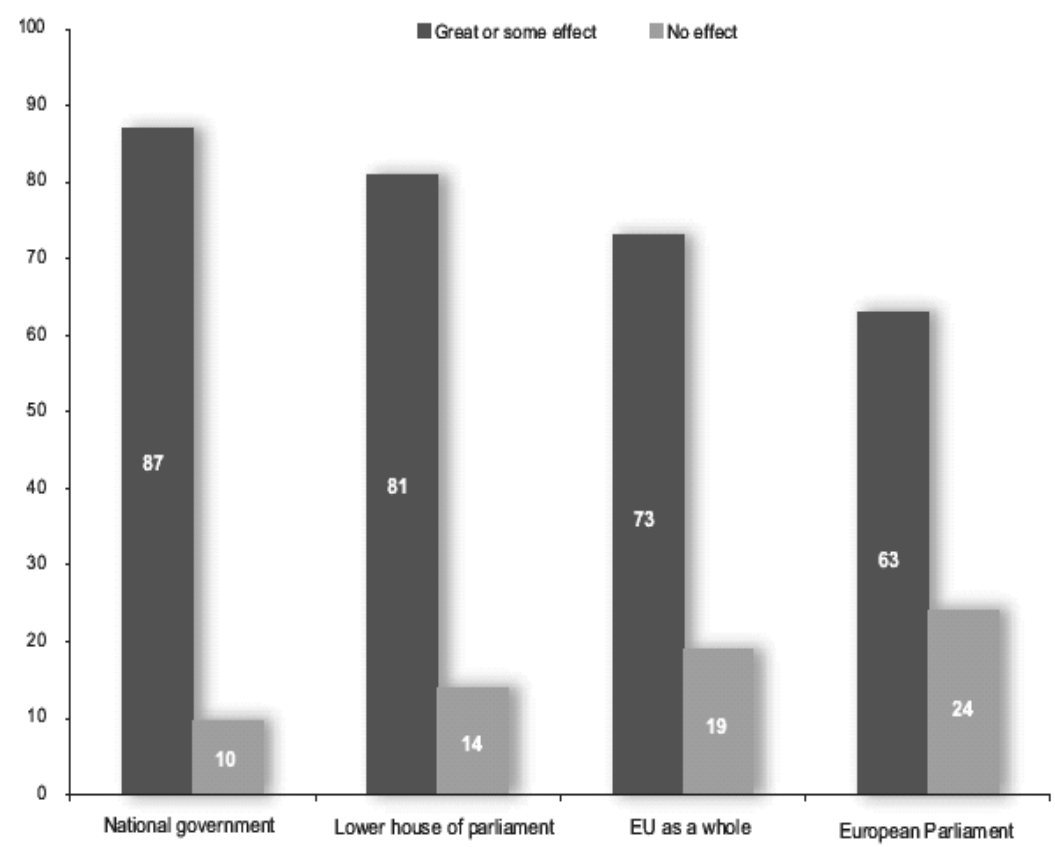

Source: Standard Eurobarometer Public Opinion Survey 61, 'European Opinion Research Group' Series, Spring 2004. p. 15

It can also be clearly seen here that the national and regional levels are still considered as more influential in the policy making compared with the supranational levels. All these confirms that for deepening, the EU has a powerful competitor; the nation-state. And without understanding the tools by which the nation-state successfully established its legitimacy, any political theorist offering a political model for the future of the EU will always face with several problems.

For this reason, the following pages will focus on the legitimisation processes of the nation-states and the relevant political theory discussions with a view to offer a probable political model for the EU. 


\section{Legitimisation processes of the European Nation-States: A Possible Inspiration for the EU?}

The general evolution of the nation-states reached to a finale with the masses' consent to the central governance structures. The nation-states used various tools for reaching this goal. Controlling of the education system and taxation, as well as providing of the basic services to the individuals were crucial in their quest for legitimacy. Elites and intelligentsia were also crucial in guiding the societies towards convergence under a single national identity. With the development of the bourgeoisie, political authority of the monarchs started to be severely questioned. Bourgeoisie, as a financially powerful new class, was capable of fighting against the existing monarchies and especially with a view to create a freer market.

During the Middle Ages individuals consent was not really important for the rulers as they were regarded mostly as subjects. However, with the institutionalisation of the nation-states the individual consent started to come to the centre of the decision making mechanisms. Following the Peace of Westphalia, an interconnected system started to flourish in Western Europe. The first signs of the institutionalisation of the state structures can be found in those years. Institutionalisation of the taxation system, enhancement of transport between princedoms' main cities and increasing communication between various regions of Europe were all first steps of the upcoming centralised state model. Incapability of the princedoms to provide basic services to the people and the increasing demand of the masses to be included within the decision making mechanisms started to pave the way for the development of the nation-state.

The era between roughly 1600 and 1800 can be considered as a period of social, intellectual and cultural transformation for most of the European countries. This period is generally named as the "Age of Reason" or the "Age of Enlightenment". On the whole, we can see two main developments in this era. The first is the triumph of the scientific revolution during the seventeenth century, which in turn formed the second development, the flourishing of critical mind during the eighteenth century. Whereas the Medieval thinkers assumed that the past knowledge was the most reliable

9 See: Bendix, Reinhard, Kings or People: Power and the Mandate to Rule, Berkeley: University of California Press, 1978 
source of wisdom, the greatest thinkers from the seventeenth century onwards rejected the ancient authorities and resolved to rely on their own minds. "Have courage to use your own reason!" (or Dare to know! - Sapere aude! $)^{10}$ started to become the main motto of the thinkers of the time who stressed the autonomy of science and the free play of the critical mind. They also started to believe that the knowledge was worthless if it could not be used. As a result, all knowledge without practical value started to be belittled and the functional knowledge has been underlined. The thinkers of the era tried to demystify the universe by the scientific method. Until the mid-seventeenth century, most people assumed that the universe was driven and inhabited by spiritual forces and humans could hardly understand and control the events. But around 1600, a mechanistic worldview started to develop. ${ }^{11}$

The most direct causes of the intellectual change in Europe came with the discovery of the New World as this challenged most of the assumptions that were introduced in the middle ages. Discovery of new islands, new lands, new peoples, and even new stars further decreased the power of the metaphysical beliefs. As a result, most of the intellectuals of the time could not escape from the attractiveness of the new rational ideas. A new flourishing publishing industry on the other hand helped Europe to diffuse the newly acquired knowledge to all the segments of the society. For the first time reading was available to a wider audience. Books, newspapers and journals could be easily found in the coffee houses and lending libraries. Also, intellectual debates started to take place in the salons of the developing bourgeoisie. Increasing of the trade and the capital accumulation has been crucial in the growth of this class. This wealthy tradesman and merchant class demanded a share of the social and political power that was formally held only by the nobility. Bourgeoisie was also influential in mobilizing the lower segments of the society and this also ignited the following French Revolution. In time, the debates of the salons have moved

${ }^{10}$ Kant, Immanuel, 'An Answer to the Question: What is Enlightenment?', in Reiss, H. S. (Ed.), Kant: Political Writings, Cambridge: Cambridge University Press, 1991. p. 54

${ }^{11}$ Lerner, Robert E., Meacham, Standish and Burns, Edward McNeill, Western Civilizations, Eleventh Edition, New York: W. W. Norton and Company Inc., 1988. p. 612 
to the streets of the cities and this has been crucial in the development of a more demanding and open-society in Europe.

The ideas that flourished prior to the French Revolution underlined the individual consent for governance. Secularisation in Western Europe and the development of Protestanism were also crucial in the development of a critical understanding against rigid and powerful institutions, most important one being the Church. Translation of Bible to various languages gave people a chance to include themselves within the interpretation processes, which also brought with itself the development of a critical mind in Western Europe. At the political level, this same questioning started to develop against the kings and lords. As a result, a well institutionalised state structure started to become an alternative for the majority of the people. ${ }^{12}$ Hereditary rulers, metaphysics and God started to be replaced by the secular institutions of state. Surely, it is difficult to argue that these institutions were considered as legitimate bodies at start. People still had a feeling of belongingness to their local communities and their kings. National identity and a feeling of belongingness to a specific nation developed in the coming decades by the backing of the newly flourishing state institutions and especially by the service providing character of the model.

Hence, it won't be wrong to consider legitimacy as a concept that has fully came to the world scene with the ideas of French revolution. Obviously, this new explanation of legitimacy as a necessary ingredient of a political regime was a major breakthrough of liberalism, which besides political suggestions of procedural democracy, also included a belief in the market society.

Today's parliamentary democracies and civil society monitored political structures have developed as a result of this historical background. The existing "social contract" tradition of Europe, coming from as early as the feudal times, also helped the development of new political models that brought the individual rights and freedoms to the centre. Surely, there have also been dark and bloody periods of the continent; however, the historical experiences and the intellectual background of the continent took Europe at

12 For a detailed analysis see: Anderson, Benedict, Imagined Communities: Reflections on the Origin and Spread of Nationalism, London: Verso, 1991. 
least to a level where democracy and social rights are generally considered as the basic minimum.

As an important contribution to the analyses of the European nationstates' (and their citizenship model's) development and evolution, Leo Huberman successfully links economics and history to create a powerful and exciting portrait of the modern age. ${ }^{13}$ Huberman shows that indeed the transformation from feudalism to capitalism played a key role in the development of the nation-states. For Huberman, any economic theory would remain limited if not backed by the historical facts. Following a Marxist logic (greatly influenced by the dialectic materialist model), Huberman argued that indeed the historical developments and particularly the class relations are the bases for all economic and social transformations, and therefore the analyses of the nation-states should also take into account this historical economic base.

During the Ancienne Régime different ethnicities, religious and cultural groups lived isolated from each other. Economically, trading has been existent; however these groups have never been totally intermingled. Yet, the end of feudalism and the start of the industrialisation necessitated more interaction between these different segments of the European societies. Factories necessitated workers from all types of backgrounds. Moreover, the pooling of the capital in the specific regions resulted in the development of the cities and the farming populations had to move to these centres to become the part of the industrialisation processes. This homogenisation in the economic relations also necessitated homogenisation in the identities. As a result, the central governance structures started to work for moulding the national identities. ${ }^{14}$ Hence, as Ernst Gellner argues, the nation-states were to a great extent the outcome of the economic transformations in the continent.

However, the European Enlightenment tradition also influenced the flourishing of the nation-state model, and to a great extent, kept its citizenship model in an inclusive form and formed its political system by democratic principles. Therefore, in the European experience, the political and social rights were not totally sacrificed during the on-going economic

${ }^{13}$ Huberman, Leo, Man's Worldly Goods, New York: Monthly Review Press, 1936.

${ }^{14}$ Gellner, Ernest, Nations and Nationalism, London: Blackwell, 1983. 
transformation in the continent; from feudalism to capitalism (industrialisation). The political revolutions, class struggles and the trade union movements of the continent have paved the ways for the flourishing of the citizenship based (inclusive, democratic and elastic) nation-state models, which are also backed by strong welfare systems.

During the $19^{\text {th }}$ and $20^{\text {th }}$ centuries, the middle and working classes were negatively affected by the industrialisation in the continent, and they grew both in numbers and social influence, as did the urban areas in which they worked and lived. The industrialisation was characterised by unique economic growth, the factory system of production and the use of new, artificially powered machines for transportation and mechanical operations. For the first time, human beings had the ability to produce far more than what was needed to sustain a large percentage of the population.

However, it was the factory owners that were getting the most of this wealth. Working class bore the burdens of the industrialisation and urban social problems such as low wages, overcrowded cities, poor medical care, insufficient social services, and a host of related problems. Therefore, the working classes started to organise and get united for their rights. Surely, Karl Marx's ideas have been crucial in the development of this solidarity. Individuals started to understand the interdependence of men on each other and the risks of the uncontrolled capitalism.

As tactfully analysed by Meryem Koray ${ }^{15}$, the outcome, the flourishing 'European Social Model' has developed in a different way compared with the other parts of the world, and to a great extent, it provided an alternative for the existing Capitalist and the Orthodox Marxist determinisms. In time, the European socialists started to fight for creating a democratic consensus with the supporters of the market model. For example, English Fabians' socialism during the $19^{\text {th }}$ century has combined the market and socialism with a view to reach at higher economic development levels for all the society. Instead of following totally individual oriented policies, they underlined the importance of society and tried to transform the market model in such a way that it functions for the benefit of all. Therefore, they did not foresee a doomsday for capitalism like the Orthodox Marxists.

${ }^{15}$ Koray, Meryem, European Social Model, Istanbul: TUSES Publications, 2002. 
One can also see a similar trend in the development of the German social democratic alternative. Here, Eduard Bernstein has been an important name. Instead of a capitalism that destructs itself due to its inherent inconsistencies, Bernstein suggested a capitalist model that aims to develop societal welfare by means of an organised public. These revisionist socialists tried to develop a healthier market model instead of totally demolishing it. The 'Revision' term started to take place of the 'Revolution' for these theoreticians. ${ }^{16}$

Following the Great Depression of 1929, the development of the Keynesian policies that underlined the importance of the state institutions for the healthy functioning of the market was also (to a great extent) a result of these arguments. The development of the social democratic policies in the 1970s (generally called as the Third Way), which tried to merge the market model and the welfare state policies, have also flourished as a result of such an understanding. Especially, the Labour Party in England and the German Social Democrats has been supportive of this model during the last decades. Third way politics, Giddens affirmed, advocated a new mixed economy. ${ }^{17}$ In the old mixed economies, markets were subordinated to the state. This new mixed economy looks instead for a synergy between the public and private sectors, utilizing the dynamism of markets but with the public interest in mind. With regards to the welfare state, Giddens recognized that it has run into a few problems, such as the sacrifice of liberty, but 'third way politics sees these problems not as a signal to dismantle the welfare state, but as part of the reason to reconstruct it'. ${ }^{18}$

In time, the trade unions have also started to act in parallel with these ideological transformations of the continent. Trade unions have been supportive of the revolution during the early years of tensions with the capital owners. Gradually, they started to fight for the improvement of their working conditions and reformation of the production cycles. Hence,

${ }^{16}$ Lee, P and Raban, C., Welfare Theory and Social Policy, London: Sage, 1988. pp. 12-33

Giddens, Anthony, The Third Way: The Renewal of Social Democracy, Cambridge: Polity Press, 1998. p. 99

${ }^{18}$ Ibid. p. 113 
instead of fighting for the demolishing of the system, they started to fight for transforming the model and thus getting a better share from it. ${ }^{19}$

As a result of all these discussions and struggles, the European continent started to experience the development of a liberal-social synthesis model. The capitalists' rights in the market have been guaranteed but in return they have accepted the role of the state to plan and govern for the societal welfare (by means of taxation), which also included an intervention to the wealth distribution. On the other hand, the working classes had to accept the capital accumulation; however, they have been given basic political/civil citizenship rights as well as social rights. ${ }^{20}$

The development of the social dimension of capitalism in Europe has also led to the redefinition of the rights throughout the continent. ${ }^{21}$ In time, the concept of the 'positive liberty' started to develop against the 'negative liberty' understanding. The philosophical concept of negative liberty is the absence of coercion from others. Here, one is considered free to the extent to which no person or person interferes with his or her activity. However, the understanding of the positive liberty necessitates the steps for supporting the individual's involvement in the political processes. ${ }^{22}$ In the European experience, a combination of the positive and negative liberties, where both the barriers on the liberties are lifted and the individuals are supported for being active players of the model, have flourished. This understanding also influenced the economic sphere. Individuals are left free for being beneficiaries of the produced wealth of the market; however, they are still supported for acquiring the minimum necessary benefits by means of the strong welfare models. Hence, the negative liberty understanding started to be balanced with a positive liberty model in Europe, both in the political and the economic spheres.

${ }^{19}$ Bell, J. D. M., 'Industrial Unionism: A Criticial Analysis' in McCarthy, W. E. J, Trade Unions, London: Penguin Books, 1972. p. 128

20 Przeworski, A., Capitalism and Social Democracy, Cambridge: Cambridge University Press, 1991. p.11

${ }^{21}$ Koray, Meryem, op. cit.

${ }^{22}$ Berlin, Isaiah, Two Concepts of Liberty, London: Clarendon Press, 1961. An inaugural lecture delivered before the University of Oxford on 31 October 1958. 
As Richard Rorty suggests; the Marxists have always been right about at least one thing: the central political questions have historically been about the relations between the rich and the poor. ${ }^{23}$ And the evolution of the European nation-states has been greatly influenced by this historical base and their institutions tried to find answers to these basic questions of the mankind.

The Enlightenment tradition, the development of a revisionist socialism and the historical experiences with the destructive influences of the industrialisation and the market forces have all contributed to the development of a stronger welfare model in the European continent. As a result, today, Europe represents the strongest social and welfare model in the world with a higher level of solidarity. Currently, Europeans are paying more taxes than many other countries' citizens for sustaining the welfare state model. Moreover, although it is limited, the EU still underlines the social and welfare policies and supports the member states in sustaining the services such as education, health and employment. However, there are also counter neo-liberal arguments, which generally underline the necessity of competitiveness in the international economy.

\section{Table-4}

\begin{tabular}{|c|c|}
\hline \multicolumn{2}{|c|}{ Main Focus Areas of Neo-Liberal and Social Democratic Models } \\
\hline Neo-Liberal & Social Democratic \\
\hline Free Market & Free Market \& Welfare State \\
\hline Individual / Individualistic Ethics & Society / Societal Ethics \\
\hline Negative Liberty & Positive Liberty \\
(Setting the Bare Minimums) & (Leading to Relative Equality) \\
\hline Negative Justice & Egalitarian Justice \\
\hline Liberal Democracy & Social Democracy \\
\hline Market Efficiency & Social Security \\
\hline Competition & Solidarity \\
\hline Equality in Opportunities & Equality in Outcomes \\
\hline
\end{tabular}

${ }^{23}$ Rorty, Richard, 'Globalisation, the Politics of Identity and Social Hope' in Rorty, Richard (Ed.), Philosophy and Social Hope, London: Penguin, 1999.

${ }^{24}$ Koray, Meryem, op. cit. p. 106 
Yet, the economically crisis prone and ecologically disastrous nature of the neo-liberal models always force the individuals to assess alternative political and economic governance forms. In this context, the social democratic alternatives seem to be a feasible option both for the national and the supranational levels.

By taking this historical background of the European continent into account, today, one can say that the choice in front of the EU is indeed quite clear. An neo-liberal EU (hypothetically more competitive ${ }^{25}$ and also politically excluding different identities/cultures to take part) where the citizens of the member-states are gradually having lesser loyalty to the supranational governance forms; or, a social-democratic EU (inclusive of differences and highly multicultural, following the footsteps of the European Social Model) where the individuals are increasingly supporting the deepening of the supranational level. Surely, the national and the supranational levels do not have to necessarily clash with each other as long as the supranational level is defined in an elastic way to include the sub identities and the social policies are followed jointly at both levels. When creating such a supranational model, the nation-state experience and modernity will still be the major guiding frameworks for the policy-makers.

In fact, during the last decades, criticisms against modernity and the nation-state institutions has increased. First, the absolute and the objective truth understanding of the Enlightenment tradition started to be questioned. 'Truth' is started to be viewed as contextual, situational, and conditional. Second, the emphasis is started to be placed on fragmentation rather than universalism, thus leaving the general and moving towards the particular. Third, the local power started to be preferred over the centralised power, and the de-centralisation, or the process of democratisation of power, started to become a pervasive theme. Fourth, the rise and consolidation of consumer culture is given as the proof of flourishing new identities and this global marketplace and globalisation in general started to be given as an alternative to the modern institutions of the nation-state. Finally, the diversity and difference started to be emphasised and valued above commonality. Although these criticisms of the so-called post-modern

${ }^{25}$ Esping-Andersen clearly proves that the social democratic models can also be as competitive as the liberal alternatives. Esping-Andersen, Gosta, The Three Worlds of Welfare Capitalism, London: Polity Press, 1990. 
thinkers are import for transforming the governance models towards more democratic forms, their ever existent critical attitude towards all the constructions leads to an unending relativism. ${ }^{26}$

As important philosopher of our time, Jurgen Habermas' reaction to these criticisms has been very powerful. For him, the individuals face a fundamental strategic choice posed in stark terms: 'hold the intentions of the Enlightenment or give up the project of modernity as lost'. ${ }^{27}$ With theory of communicative action Habermas defends the 'project of modernity' and argues that "a modernity at variance with itself of its rational content and its perspective on the future" can exist. Habermas claims that the project of modernity was 'unfinished' and contained unrealised capacity for emancipatory potential. Such potential draws on the specialisation of culture for the enrichment of daily life and simultaneously the rational organisation of everyday life and experience. For Habermas, the two need not be opposed. The project of modernity has undiminished potential to increase social rationality, justice and morality. But this potential can be realised only by cognitive progression and support for the moral boundaries of rationality, which remains the task of philosophy and social theory.

On the whole, Habermas argues that the modernity can be transformed into an inclusive form towards all the differences. Hence, modernity is elastic enough to answer the criticisms of the post-modern (and communitarian) and this also makes going beyond modernity an impossible task. Habermas also accuses the post-modern thinkers because for him they are using the same tools of rationality when trying to demolish it. ${ }^{28}$

For Habermas, the transformation of the existent political models towards such an inclusive form necessitates communication between all the levels of the society. To this end, Habermas underlines the importance of the civil society organisations and stresses the necessity of developing an appropriate legal framework for their inclusion to the decision making mechanisms. Due to its rational basis the modernity has infinite potential for

${ }^{26}$ Powell, Jason and Moody, Harry, 'The Challenge of Modernity: Habermas and Critical Theory' in Theory and Science, Volume 4, Issue 1, Spring 2003.

${ }^{27}$ Habermas, J., The Philosophical Discourse of Modernity, Cambridge: Polity Press, 1984. p.35

${ }^{28}$ Ibid. pp. 83-106 
elasticity. What is necessary is then; further modernity and enlightenment for Habermas.

Following Habermas this paper argues that this type of a transformation is also possible at the EU level. With the increasing capabilities of Brussels, this process can be easier. In an effectively working political model, a supranational European identity defined by values and societal ethics inclusive all the sub-identities is not an utopia. ${ }^{29}$ This will be a new form of identity permitting the existence of various religious, cultural and ethnic identities both at the supra and the sub levels. As a result of the development of such an understanding, the clash of the national and the supranational levels may also be a part of history, at least in this geography.

A solely federalist EU that is established on procedural democracy may remain limited in including the citizens within the political processes and keep the EU as an elite project without an active civil society involvement. This will still be true even if we accept the developing supranational political structures as the results of the class struggles and hence the economic realms, similar to the nation-state experience as explained by Gellner and Huberman. In an era when the modern nation-states are puzzled with respect to the criticisms related to democratic participation and civil society involvement, its exact replica in a bigger and multicultural geography will surely be problematic. Therefore, the EU can be the arena where the current problems of the nation-states are tried to be solved, but this time at the supranational level.

On the whole, this move to a legitimacy conceptualisation based on participation and inclusivity is crucial as it also shows the path that EU legitimacy will most likely follow in future. Yet, it is difficult to argue that there are adequate theoretical discussions in political theory, which goes beyond the nation-state and consider a supranational body such as EU to have a participatory governance structure. Recent discussions on the 'multilevel governance' are surely important steps in that direction. Even the transformation of the word from 'government' (implying the "governor and the governed") to 'governance' (implying joint government with communication between the ruler and the ruled) shows the way that the EU

${ }^{29}$ Habermas, J., The Postnational Constellation: Political Essays, Massachusetts: MIT Press, 2001. pp. 5-19 
should follow. Only, in this type of an elastic and participatory political structure the EU can deepen and legitimise itself.

Today, the European integration represents the possibility of a 'new model' in which the existing nation-states that are established on the classical liberal model transform and converge at the supranational level. Moreover, some of the basic services of nation-states are still provided and even in a more efficient way within the EU. There still is a 'common good' defined by Brussels for the societies of all the member states. However, because of its massive geographic dimension and the existence of various ethnicities, cultures and religions within, the consensus on the common good is much more difficult and this increases the importance of participation in the decision making mechanisms. The need for homogenisation in the industrial age that is explained in detail by Gellner may take place on a different level within the EU. In today's postindustrialist world the communication networks are more developed and individuals do face different cultures, ethnicities and lifestyles. Production is not anymore limited to factories and the need for migration to cities is decreasing. The states are in fact following policies to further develop the regions. As a result, different ethnicities, cultures, religions and lifestyles can easily take part within the production and economic life today. Moreover, the effects of globalisation and a global world economy decrease the need for a homogeneous world.

However, with respect to political identity, there still exists a need for homogeneity at least for definitive purposes. Individuals may keep their ethnic, cultural and religious differences in both public and private spheres as long as the public sphere is defined by democracy. This type of a public sphere also permits the living of the differences within the state structures and leads to a hybrid supranational identity as the unifying element.

Hence, instead of seeing nationalism as the only theory of political legitimacy today, democracy and social rights (as a new form of internationalism) may be taken as the legitimizing elements for the EU. Within the EU, political rights and democratic values may be the upper identity of the European citizens which makes the existence of differences possible both at private and public spheres. Additionally, the existence of social rights will be crucial for the successful functioning of this model in the long run. By the input (political rights) and the output (social rights) 
dimensions, the well-established historical national forms may this time be taken to a post-national level.

\section{General Conclusions}

One of the major arguments in this paper is that shared ethnic-cultural identity is not a necessary condition for the legitimacy of the state authority if the state is a genuinely democratic body. As Habermas puts it; 'The citizens of a democratic legal state understand themselves as the authors of the law, which compels them to obedience as its addressees. ${ }^{30}$ Therefore, the non-existence of the feeling of Europeanness (or Europeanism) is not a major problem at this stage for the EU, as it can also be created in the long run. Similarly, Jacques Delors once called today's Europe a 'UPO' - an Unidentified Political Object. Hence, the clear limits of Europeanness (or Europeanism) can be developed in future. However, the basic preconditions for its legitimisation will always be same with the experiences of the other political forms. To this end, the most important precondition is the democratic participation of the individuals, which was also crucial in the legitimisation of the nation-state structures.

Yet, besides elaborating on the democracy dimension, this paper also argued that the EU will have to follow social policies for further deepening. In fact, this was again the lesson from the nation-state experience. The service providing characters of the nation-states have been crucial for their legitimisation. Tzvetan Todorov asks; 'What does Europe need strength for?' And answers; to defend a certain identity which the Europeans think is worth defending. ${ }^{31}$ For Todorov, this identity includes democracy, rationality and justice. This paper also underlined similar issues. Besides a democratic outlook which is rational in its attitudes through the existence of critical mind, what is necessary for such an identity is the justice element that protects the common good. Here, the social and welfare policies are suggested to achieve this type of an all-inclusive justice.

Overall, this paper underlined the 'input' and 'output' dimensions of legitimacy and has taken the nation-state experience as its main starting

${ }^{30}$ Habermas, J., The Postnational Constellation: Political Essays, Massachusetts: MIT Press, 2001. p.133

${ }^{31}$ Todorov, Tzvetan, Le Nouveau Désordre Mondiale, Paris: Robert Laffont, 2003. p. 87 
point. However, this does not mean that: first, the nation-state does not necessitate change, and secondly, the EU should be the exact replica of the nation-state model.

That said, this paper still underlined the nation-state as a major inspiration for the supranational level because the nation-state experience shows us that the most important political questions did not change for centuries. Democratic participation and the will to solve the material problems of the individuals have always been the main focus points all the successful political bodies. Particularly, the European nation-states and the European Social Model have historically managed to partly answer these basic questions and therefore the utilisation of these experiences during supranational policy development may act as a catalyst for the transformation and the strengthening of the EU institutions.

Surely, the EU will not be and cannot be an enlarged copy of a nationstate, just as nation-states were not and could not be bigger versions of estates, parishes or municipalities. ${ }^{32}$ Therefore, the EU should opt for finding its own unique route. In this context, this paper proposes a hybrid supranational identity, which is backed by civil society and post-national welfare models.

The democratisation of the EU is strongly related with the individuals increasing feeling of belongingness to the supranational institutions. Procedural steps to further develop the democratic structures of the EU are necessary but not sufficient conditions. What is necessary is then a more colourful definition of the self and the further inclusion of the civil society organisations to the political processes. Yet, such a radical democratic outlook defined by multiculturalism and a totally civilian political model is not enough. For the Kantian model of perpetual peace, the EU should also be capable of solving the material problems of the individuals.

In today's world, the EU's has the task of bringing back together the power and the politics, presently separated and navigating in opposite directions. The power to rule is tried to be established by security oriented states and the politics (which has always been related with who gets what) is left to the hands of the pure market forces. On the contrary, this paper has

${ }^{32}$ Bauman, Zygmunt, op. cit. p. 135 
suggested that, similar to the European Continent's historical experiences, the EU should work for bringing the power and politics together.

In fact, following 'Great Depression' the nation-states managed to realise this task, which is tactfully analysed by Karl Polanyi in his 'Great Transformation'. In Bauman's words; 'The project of freedom from fear pursued through the social state was perhaps the boldest endeavour ever consciously undertaken by humanity, along with the resolve it gathered to see it through. ${ }^{33}$ Similarly today, the EU has to be bold enough to go through a similar process and needs to start another 'Great Transformation' at the supranational level. With such a transformation, the national social models ${ }^{34}$ and experiences of the European continent may be for the first time taken to the European level, which Habermas calls as Post-National Constellation; and this endeavour, at a later stage, can even inspire the flourishing of a Global Governance model.

${ }^{33}$ Bauman, Zygmunt, op. cit. p. 33

${ }^{34}$ Meryem Koray uses the 'European Social Model' term for summarising the democratic and social rights related common charateristics of the European nationstates, and also suggests the further deepening and institutionalisation of this model for the success of supranational/EU policy making in Europe. Koray, Meryem, European Social Model, Istanbul: TUSES Publications, 2002. 


\section{References :}

Anderson, Benedict, Imagined Communities: Reflections on the Origin and Spread of Nationalism, London: Verso, 1991.

Balibar, Etienne, 'Europe: Vanishing Mediator', Constellations, Volume 3, 2003.

Bauman, Zygmunt, Europe: An Unfinished Adventure, Cambridge: Polity Press, 2004.

Bell, J. D. M., 'Industrial Unionism: A Criticial Analysis' in McCarthy, W. E. J, Trade Unions, London: Penguin Books, 1972.

Bendix, Reinhard, Kings or People: Power and the Mandate to Rule, Berkeley: University of California Press, 1978.

Berlin, Isaiah, Two Concepts of Liberty, London: Clarendon Press, 1961. An inaugural lecture delivered before the University of Oxford on 31 October 1958.

Esping-Andersen, Gosta, The Three Worlds of Welfare Capitalism, London: Polity Press, 1990.

Gellner, Ernest, Nations and Nationalism, London: Blackwell, 1983.

Giddens, Anthony, The Third Way: The Renewal of Social Democracy, Cambridge: Polity Press, 1998.

Habermas, J., The Philosophical Discourse of Modernity, Cambridge: Polity Press, 1984.

Habermas, J., The Postnational Constellation: Political Essays, Massachusetts: MIT Press, 2001.

Habermas, Jurgen, 'Citizenship and National Identity: Reflections on the future of Europe' in Praxis International, Volume 12, 1992.

Huberman, Leo, Man's Worldly Goods, New York: Monthly Review Press, 1936.

Kant, Immanuel, 'An Answer to the Question: What is Enlightenment?', in Reiss, H. S. (Ed.), Kant: Political Writings, Cambridge: Cambridge University Press, 1991.

Koray, Meryem, European Social Model, Istanbul: TUSES Publications, 2002.

Lee, P and Raban, C., Welfare Theory and Social Policy, London: Sage, 1988.

Lerner, Robert E., Meacham, Standish and Burns, Edward McNeill, Western Civilizations, Eleventh Edition, New York: W. W. Norton and Company Inc., 1988.

Marshall, T. H., Citizenship and Social Class, London: Cambridge University Press, 1950.

Polanyi, Karl, The Great Transformation, New York: Beacon Press, 2001. 
Powell, Jason and Moody, Harry, 'The Challenge of Modernity: Habermas and Critical Theory' in Theory and Science, Volume 4, Issue 1, Spring 2003.

Przeworski, A., Capitalism and Social Democracy, Cambridge: Cambridge University Press, 1991.

Rorty, Richard, 'Globalisation, the Politics of Identity and Social Hope' in Rorty, Richard (Ed.), Philosophy and Social Hope, London: Penguin, 1999.

Scharpf, Fritz, Governing in Europe: Effective and Democratic?, New York: Oxford University Press, 1999.

Seymour M. Lipset and Stein Rokkan (Eds.), Party Systems and Voter Alignments: Cross-National Perspectives, New York: Free Press, 1967.

Eurobarometer, Standard Eurobarometer Public Opinion Survey 61, 'European Opinion Research Group' Series, Spring 2004.

Todorov, Tzvetan, Le Nouveau Désordre Mondiale, Paris: Robert Laffont, 2003. 